\title{
Double Strand Break Repair
}

National Cancer Institute

\section{Source}

National Cancer Institute. Double Strand Break Repair. NCI Thesaurus. Code C19608.

Mechanisms of DNA repair associated with radiation damage. 